\title{
MMR2 vaccination coverage and timeliness among children born in $2004-2009$ : a national survey in Saint Lucia, 2015
}

\author{
Sharon Belmar-George, ${ }^{1}$ Julietta Cassius-Frederick, ${ }^{2}$ Phil Leon, ${ }^{1}$ \\ Sonia Alexander, ${ }^{3}$ Yvette Holder, ${ }^{3}$ Karen Nadine Lewis-Bell, ${ }^{4}$ \\ M. Carolina Danovaro-Holliday, ${ }^{5}$ and Pamela Bravo-Alcántara ${ }^{6}$
}

Suggested citation Belmar-George S, Cassius-Frederick J, Leon P, Alexander S, Holder Y, Lewis-Bell KN, et al. MMR2 vaccination coverage and timeliness among children born in 2004 - 2009: a national survey in Saint Lucia, 2015. Rev Panam Salud Publica. 2018;42:e76. https://doi.org/10.26633/RPSP.2018.76

ABSTRACT Objectives. To more accurately determine coverage and timeliness of the second dose of measles-mumps-rubella vaccine (MMR2), while identifying factors associated with low $M M R 2$ vaccination uptake among children in Saint Lucia.

Methods. A survey was conducted in October - November 2015 targeting children born in 2004 - 2009. At 86 preschools and primary schools, two children from each grade were randomly selected, yielding an effective sample of 836 children. Health records were reviewed to assess vaccination coverage and timeliness. Parents and/or guardians and principals of all 86 schools were interviewed regarding knowledge, attitudes, and practices related to vaccination.

Results. Of 767 children included, $75 \%$ were vaccinated with MMR2 ( $n=572)$; $46.7 \%$ were vaccinated in a timely manner, i.e., by 5 years of age. Cohorts born in 2004, 2005, and 2008 reported the lowest proportion. 'Mothers as caregivers' was positively associated with timely MMR2 vaccination. Although 97\% of principals surveyed considered vaccination important, $48.8 \%$ were not aware of national legislation requiring complete vaccination prior to school entry. Survey results concurred with the low $M M R 2$ administrative coverage rates reported by Saint Lucia, much lower than the recommended $95 \%$.

Conclusions. Based on the results of this survey, Saint Lucia's national immunization program has lowered the age of MMR2 to 18 months in 2016, increased advocacy with schools to enforce the school-entry law, and is working to vaccinate the cohorts of children who have not received timely $M M R 2$.

Keywords Measles-mumps-rubella vaccine; mass vaccination; immunization programs; Saint Lucia; West Indies.

Ministry of Health, Wellness, Human Affairs, and Gender Relations, Castries, Saint Lucia.

2 Expanded Immunization Program, Ministry of Health, Wellness, Human Affairs, and Gender Relations, Castries, Saint Lucia.

3 Consultant, Pan American Health Organization (PAHO), Regional Office of the World Health
Organization (WHO), Washington, DC, United States.

4 Jamaica Country Office, PAHO/WHO, Kingston, Jamaica.

5 Department of Immunization, Vaccines, and Biologicals, Expanded Program on Immunization, WHO, Geneva, Switzerland.
Comprehensive Family Immunization Unit, De partment of Family Health Promotion and Life Course. PAHO/WHO, Washington, DC, United States of America. Send correspondence to Pamela Bravo-Alcántara, bravopam@paho.org 
The Pan American Health Organization (PAHO) recommends at least 95\% coverage at the national level for both doses of measles-rubella vaccine in order to sustain the Regional elimination of these diseases (1). Additionally, two doses are required for primary immunization to protect children who do not develop protective immunity after the first dose (2). In Saint Lucia, a Caribbean nation of almost 170000 inhabitants, vaccination coverage among children less than 2 years of age reached levels above 95\% in 2010 - 2014. Nevertheless, annual administrative data for the second dose of measles-mumps-rubella vaccine (MMR2) ranged from $62 \%-79 \%$ among children aged 4 years during the same period (3). As part of a strategy to ensure high vaccination coverage rates, the country has a law requiring vaccination prior to school entry (4). This approach should be fairly effective given that enrollment in primary schools is $96.7 \%$ among children 5 - 11 years of age (5).

Low MMR2 administrative coverage does not guarantee herd immunity and increases the risk of a measles or rubella outbreak if a virus introduction occurs. Saint Lucia is particularly susceptible due to the continual influx of tourists from around the world. Administrative coverage is calculated by dividing the number of vaccine doses administered by the number of children in the target age group. Calculations are affected by data quality issues (6), both in denominators (e.g., outdated census) and numerators (e.g., incomplete or incorrect reporting), and do not include information on exact age at vaccination, making it impossible to assess timeliness of administration.

The Ministry of Health of Saint Lucia conducted a nationwide coverage survey to more accurately determine MMR2 coverage, timeliness of vaccination, reasons for non-vaccination, and predictors of delayed or missed vaccination, as well as to better assess the schools' knowledge and practices regarding vaccination. The survey was conducted in October - November 2015 and targeted children born in 2004-2009.

\section{MATERIALS AND METHODS}

\section{Study setting}

Saint Lucia, one of the Windward Islands, is located northeast of Saint Vincent and the Grenadines, northwest of Barbados, and south of Martinique. In 2012, the population was officially estimated at 169115 inhabitants, with annual live births of 2300 . Administratively, it is divided into 11 districts (parishes), but for health planning and implementation, the country has eight health regions (5). Based on the 2015 World Bank Gross National Income per Capita, Saint Lucia is considered an upper-middleincome country (7).

The Expanded Program on Immunization (EPI) in Saint Lucia commenced in 1977. Since 1980, the country has been procuring vaccines through the PAHO Revolving Fund, a pooled mechanism to purchase high-quality life-saving vaccines and related products at the lowest price. Immunization services are provided by community health nurses through 33 public health facilities, one polyclinic, and two district hospitals within the health regions. Immunization services for children are also offered by the private sector through five pediatricians and some general practitioners. Vaccines offered in the private sector are obtained primarily from the Ministry of Health.

Full vaccination status is required by law for entry into primary school. The Public Health Act, which was approved in 1975 and revised in December 2001, requires vaccination of all children in Saint Lucia before 6 years of age (4). Exemptions are allowed for medical reasons or religious beliefs. School principals are tasked to ensure compliance with these regulations. Primary education is compulsory for all children 5-11 years of age and had achieved a gross enrollment rate of $96 \%$ in 2012 and 2013 (8).

\section{Survey design}

From 2 October - 6 November 2015, a vaccination coverage survey using schools as the sampling frame was conducted among children $6-11$ years of age, born in 2004 - 2009. The second dose of MMR vaccine is administered at 4 years of age in Saint Lucia; therefore, the age range chosen for the study gave ample time for complying with the vaccination requirement.

The sampling frame was all children attending all 86 public and private schools in grades $\mathrm{K}-5$ and in schools serving children with special needs, which do not have grades. A stratified sample was used in each grade in all 86 schools. The sampling list was alphabetically ordered by the student's last name. Two children were randomly selected from each grade and school, using the random generator function in Microsoft Excel ${ }^{\mathrm{TM}}$ (Microsoft Corp., Redmond, Washington, United States). Two children were also randomly selected at each of the six special education schools. Sample size was calculated assuming MMR2 national coverage at $75 \%$ and allowing for a $10 \%$ non-response rate, with $80 \%$ power to provide estimates of indicators with $5 \%$ precision and 95\% Confidence Intervals (95\%CI). This achieved a total sample of 836 children.

The principals of all 86 schools $(n=86)$ were also interviewed regarding their knowledge and attitudes about vaccinations.

\section{Data collection}

Even though data selection used a school sampling frame, interviews were conducted in the homes of the selected children. After obtaining verbal consent, trained surveyors (nursing students) interviewed caregivers using a standard questionnaire that was adapted to Saint Lucia; it had been piloted and revised. Information was collected on sociodemographic factors in broad categories: place of residence, demographics, household characteristics, attitudes of the caregiver towards vaccination, and reasons for non-vaccination.

Interviewers verified the vaccination status of the sampled students by photographing and reviewing their immunization cards, thus effectively collecting the entire vaccination schedule. If the immunization card was not available, surveyors sought vaccination history from immunization records at local health facilities where the children had been vaccinated. Surveyors were supervised by senior district nurses who also administered the school questionnaire. To minimize bias, supervising nurses were assigned to districts other than those in which they normally work.

Data was double-entered into a data file, validated, and edited using Epi Info $^{\mathrm{TM}}$ (Centers for Disease Control and Prevention, Atlanta, Georgia, United States). IBM SPSS Statistics software, version 22 (SPSS Inc., an IBM company, Chicago, Illinois, United States) was used for data analysis, Chi-square tests, and logistic regression modelling. Although probability of selection was not calculated and the analysis was not weighted, 
survey results confirmed the existence of a low proportion of children vaccinated with MMR2.

The survey was conducted as part of the standard procedure to evaluate the activities of the Ministry of Health. As such, Saint Lucia's ethical research committee and the PAHO institutional review board considered it exempt from ethics committee approval. Nevertheless, informed consent was sought and confidentiality was maintained.

\section{Outcome measures}

A child was consider not vaccinated with MMR2 if there was no evidence of it on the immunization card or if the caregiver did not present the immunization card and no evidence was found in the public immunization record. To assess delays in vaccination, Saint Lucia's recommended vaccination schedule was followed. To this end, acceptable timing was defined as receiving MMR2 at 4 years of age or within 364 days (before turning 5 years old). Doses applied at $5-6$ years of age (61 - 72 months) were considered "untimely," but are included in the national coverage; and doses applied after 6 years of age (> 72 months) are considered "late" and are not included in coverage for age.

\section{RESULTS}

\section{Sample description}

From the sample size of 836 children, a total of 767 caregivers were interviewed, yielding a $91.7 \%$ response rate. Sixty-nine interviews were not completed due to an inability to locate the caregiver's household $(7.2 \%)$, lack of caregiver consent $(0.8 \%)$, and incomplete questionnaires $(0.2 \%)$. Sampled children were evenly distributed among the age group of 6-11 years of age. Principals or senior officers in all 86 schools were interviewed.

\section{Vaccination status}

Table 1 describes the characteristics of the surveyed children and their households. Of 767 children 6 - 11 years of age, $75 \%$ (95\% CI: 71.1 - 78.0) had proof of having received the MMR2 vaccine. The proportion of these children receiving the diphtheria and tetanus (DT) vaccine and the fifth dose of polio vaccine, both of which are administered concurrent to MMR2, was also less than $80 \%$.

The proportion of vaccinated children was higher in the public than in the private sector $(76.2 \%, 95 \%$ CI: $72.9-79.3$ vs. $60.0 \%, 95 \% \mathrm{CI}: 46.5-72.4)$. Users of public health facilities for vaccination services $(92.2 \%)$ were generally satisfied with the service, the attitude of health personnel $(89.5 \%)$, and the operating hours $(78.4 \%)$, but they were less satisfied with the waiting times (59.1\%). On the other hand, caregivers who chose vaccination in the private sector had a preference for individual attention, an interest in confidentiality, and had the perception that vaccines in the private sector are more effective.

The proportion of children vaccinated varied by health region, with regions

TABLE 1. Selected characteristics of children born in $2004-2009$ with at least two documented doses of measles-mumps-rubella vaccine, Saint Lucia, 2015

\begin{tabular}{|c|c|c|c|c|c|c|c|c|c|c|c|c|c|}
\hline & & \multicolumn{12}{|c|}{ Year of birth ${ }^{\mathrm{a}}$} \\
\hline & & \multicolumn{2}{|c|}{$\begin{array}{c}2004 \\
(n=105)\end{array}$} & \multicolumn{2}{|c|}{$\begin{array}{c}2005 \\
(n=89)\end{array}$} & \multicolumn{2}{|c|}{$\begin{array}{c}2006 \\
(n=94)\end{array}$} & \multicolumn{2}{|c|}{$\begin{array}{c}2007 \\
(n=99)\end{array}$} & \multicolumn{2}{|c|}{$\begin{array}{c}2008 \\
(n=90)\end{array}$} & \multicolumn{2}{|c|}{$\begin{array}{c}2009 \\
(n=95)\end{array}$} \\
\hline & & $n$ & $\%$ & $n$ & $\%$ & $n$ & $\%$ & $n$ & $\%$ & $n$ & $\%$ & $n$ & $\%$ \\
\hline Gender & Male & 57 & 54.3 & 44 & 49.4 & 51 & 54.3 & 66 & 66.7 & 45 & 50 & 52 & 54.7 \\
\hline \multirow{2}{*}{ Parental marital status } & Common-law married & 34 & 32.4 & 26 & 29.2 & 29 & 30.9 & 34 & 34.3 & 34 & 37.8 & 29 & 30.5 \\
\hline & Other & 10 & 9.5 & 12 & 13.5 & 17 & 18.1 & 12 & 12.1 & 10 & 11.1 & 14 & 14.7 \\
\hline \multirow[t]{3}{*}{ Parental education level } & Primary or less & 38 & 36.2 & 40 & 44.9 & 34 & 36.2 & 32 & 32.3 & 27 & 30 & 28 & 29.5 \\
\hline & Secondary & 42 & 40 & 30 & 33.7 & 39 & 41.5 & 44 & 44.4 & 46 & 51.1 & 47 & 49.5 \\
\hline & Tertiary & 13 & 12.4 & 8 & 9 & 9 & 9.6 & 9 & 9.1 & 10 & 11.1 & 13 & 13.7 \\
\hline Parental employment & Unemployed & 30 & 28.6 & 33 & 37.1 & 29 & 30.9 & 32 & 32.3 & 39 & 43.3 & 31 & 32.6 \\
\hline \multirow[t]{3}{*}{ Relationship to child } & Mother & 93 & 88.6 & 75 & 84.3 & 80 & 85.1 & 76 & 76.8 & 76 & 84.4 & 86 & 90.5 \\
\hline & Father & 4 & 3.8 & 4 & 4.5 & 7 & 7.4 & 12 & 12.1 & 3 & 3.3 & 2 & 2.1 \\
\hline & Other & 8 & 7.6 & 10 & 11.2 & 7 & 7.4 & 11 & 11.1 & 11 & 12.2 & 7 & 7.4 \\
\hline \multirow[t]{3}{*}{ Age of caregiver } & $<35$ years & 37 & 35.2 & 35 & 39.3 & 44 & 46.8 & 42 & 42.4 & 45 & 50 & 60 & 63.2 \\
\hline & $35-44$ years & 40 & 38.1 & 28 & 31.5 & 32 & 34 & 37 & 37.4 & 31 & 34.4 & 26 & 27.4 \\
\hline & $>45$ years & 27 & 25.7 & 25 & 28.1 & 18 & 19.1 & 20 & 20.2 & 14 & 15.6 & 9 & 9.5 \\
\hline
\end{tabular}

${ }^{a}$ The total sample provided in each year of birth does not account for non-responses under each social characteristic.

Source: Prepared by the authors from the study results. 
1 and 7 having the lowest rates $(62.7 \%-$ $66.0 \%)$ and regions 4 and 5, the highest $(80.1 \%-85.3 \%)$. Region 1 consistently had the lowest proportion of fully vaccinated children according to the immunization schedule. Among caregivers who claimed that children were fully vaccinated with MMR2 ( $n=321)$, just $61.4 \%$ had, in fact, received their second dose. The most frequent reason for non-vaccination was that caregivers postponed it despite being aware that their children needed the vaccine, followed by being unaware of where to go for vaccination.

For 534 children $(69.7 \%)$, data were obtained from an immunization card, while for $27.4 \%$, vaccination records were obtained from the local health facility. For $2.9 \%$ of surveyed children, it was not possible to retrieve written record of vaccination status; these 22 children were considered not vaccinated with MMR2. Two of every five persons $(41.6 \%)$ did not know that the law requires children to be fully vaccinated before entering school. The demographics of those unaware of the law were not significantly different from the demographics of the rest of the population.

\section{Factors associated with timely vaccination}

As Figure 1 shows, $46.7 \%$ of children were vaccinated with MMR2 on time (before 5 years of age); $23.9 \%$ were vaccinated 1 year later (untimely); and $4.4 \%$ were vaccinated by 11 years of age (late). Children born in 2009 were vaccinated in a timelier manner than those in other birth cohorts, but the proportion never exceeded $80 \%$. Additionally, with the exception of one region that reported the lowest rate of untimely vaccination, in all other regions more than one-half of the children did not receive the MMR2 vaccination on time.

In completely vaccinated cohorts ( $n=572)$, age-appropriate vaccination with MMR2 was significantly more likely $(P<0.05)$ if the child had a mother as caregiver (Table 2 ). Age was positively associated with timely MMR2 vaccination among caregivers less than 35 years of age, but it was not identified as an independent factor in the logistic regression model.

Likewise, caregiver perception on the importance of vaccines and safety was not associated with age-appropriate MMR2 vaccination. Other variables explored in

FIGURE 1. Curve showing the proportion of children $(n=572)$ vaccinated with MMR2, by age at time of vaccination, Saint Lucia, 2015

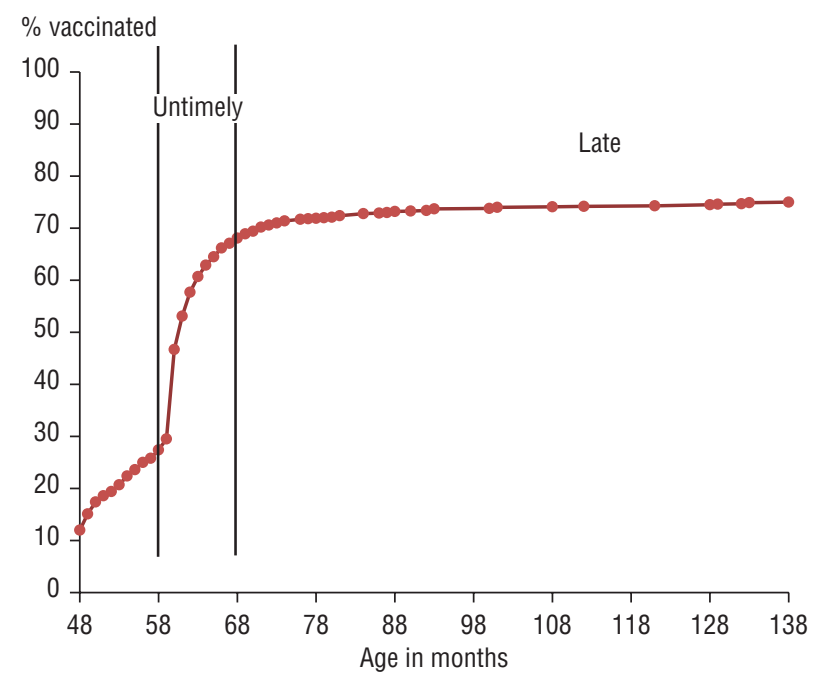

Source: Prepared by the authors from the study results.

TABLE 2. Analysis of the predicting factors for age-appropriate MMR2 vaccination among children $6-11$ years of age $(n=767)$, Saint Lucia, 2015

\begin{tabular}{lccccccc}
\hline Variables & $n$ & $\%$ & $\begin{array}{c}\text { Odds } \\
\text { Ratio }\end{array}$ & $\begin{array}{c}95 \% \text { Confidence } \\
\text { Intervals }\end{array}$ & $\begin{array}{c}\text { Adjusted Odds } \\
\text { Ratio }\end{array}$ & $\begin{array}{c}95 \% \text { Confidence } \\
\text { Intervals }\end{array}$ & $P$-Value \\
\hline Mother as caretaker & 633 & 82.5 & 1.65 & $1.13-2.43$ & 1.56 & $1.05-2.31$ & 0.03 \\
Caretaker < 35 years of age & 347 & 45.2 & 1.35 & $1.01-1.79$ & 1.30 & $0.95-1.77$ & 0.10 \\
Single caretaker & 328 & 42.8 & 0.94 & $0.70-1.25$ & 0.89 & $0.66-1.20$ & 0.44 \\
Incomplete secondary education & 347 & 45.2 & 1.04 & $0.79-1.39$ & 1.14 & $0.83-1.56$ & 0.42 \\
Fully employed & 469 & 61.1 & 0.90 & $0.67-1.20$ & 0.96 & $0.71-1.31$ & 0.80 \\
Vaccinated in a public facility & 707 & 92.2 & 1.00 & $0.59-1.70$ & 0.91 & $0.52-1.58$ & 0.73 \\
Vaccines are important & 729 & 95 & 2.35 & $0.82-6.73$ & 0.83 & $0.42-1.67$ & 0.61 \\
Vaccines are safe & 520 & 67.8 & 1.25 & $0.92-1.70$ & 1.30 & $0.94-1.79$ & 0.12 \\
\hline
\end{tabular}

adjusted for all other variables reported in the column.

Source: Prepared by the authors from the study results.

the logistic model were not associated with timely vaccination.

\section{Awareness among school principals}

Of the 86 school principals interviewed, only $36 \%$ were aware of the immunization schedule, while $40 \%$ were somewhat familiar with the schedule. Additionally, $48.8 \%$ of principals were not aware of the school-entry vaccination law or policy, while $25.6 \%$ knew of both the law and the immunization schedule. No significant differences were found between rural and urban schools.

Although $97.7 \%$ of principals agreed that vaccines are important, mainly because they protect children from diseases, only $45.9 \%$ were certain that vaccines are safe. The possibility of severe adverse events was identified as the main safety concern among the school principals. Nevertheless, $97.6 \%$ of principals would encourage parents to have their children fully vaccinated. Most respondents received information on vaccination from Ministry of Health officials, but a significant proportion $(51.2 \%)$ found information through the Internet. Finally, most schools $(71 \%)$ did not keep copies of immunization cards on file.

\section{DISCUSSION}

Like other countries in the Americas, Saint Lucia has strived to maintain high, homogeneous vaccination coverage $(95 \%)$ in every municipality as a cornerstone strategy for sustaining the elimination of measles, rubella, and congenital rubella syndrome $(9,10)$. Continued coverage beneath this level results 
in a growing population of susceptible children who will become incompletely vaccinated adolescents and young adults, creating the potential for re-introduction of these diseases. This study confirmed the hypothesis that the national MMR2 coverage rate is below the recommended $95 \%$, concurring with reports that MMR2 coverage has ranged from $62 \%-79 \%$ in 2010 - 2014.

National efforts to improve MMR2 coverage have produced positive results, as the proportion of vaccinated children born in 2009 was higher than those born in 2004 - 2008. Indeed, the proportion increased from $70.4 \%$ in 2005 to $80.8 \%$ in 2009 despite some fluctuations. Nevertheless, these results were still far short of the optimal $95 \%$ threshold required to ensure herd immunity against measles and rubella. Not only were nearly $20 \%$ of the respondents unvaccinated with MMR2, but of those vaccinated $(n=572)$, less than one-half were vaccinated on time. In fact, $29 \%$ were vaccinated up to 5 years late. Despite a setting with good access to all vaccines, the presence of a pool of children with incomplete or delayed MMR2 vaccination increases the risk of measles or rubella outbreaks if a virus importation occurs.

The study identified having a mother as caregiver as an independent protective factor for timely MMR2 vaccination. Traditionally, mothers have frequent contact with the health services, especially maternal and child health services during pregnancy and the perinatal period. It may be argued that continued contact with both mother and child is easier, certainly during the first year, than it might be with a guardian. Initiating and maintaining contact with a guardian requires additional effort. Unlike other surveys, the level of education of caregivers was not significantly associated with a higher proportion of vaccinated children or timeliness, $(11-15)$.

Parents and caregivers reported that they were aware that their child was due for a vaccination, so lack of knowledge was not an issue. This attests to competence of health officials serving as effective conduits of vaccination information. The main reason given for untimeliness was postponement. This seems to imply that parents and caregivers do not have the same sense of urgency regarding MMR2 as they had with the first dose (91\% timely). Perceptions may exist that older children are less vulnerable.
Also, contact with health services is less frequent for preschoolers than for infants, and without reminders, parents and caregivers are more likely to miss appointments, especially if the parents are employed.

In addition, visits to the health facilities for vaccination are frequent during the first year of life. Often, health care workers indicate to parents that after the primary series of vaccines, the child is fully immunized and only boosters are needed. Thus, parents may equate the receipt of the first dose of MMR vaccine with being fully immunized. Therefore, parents may recall that their children are fully immunized, but they may not be up-to-date.

Although the present study did not find employment to be significantly associated with timeliness of MMR vaccination, another study, conducted in Haiti by Tohme and colleagues (14), found a significant correlation between an employed person in the household and non-vaccination (14). It could be that employers are less willing to give a parent or caregiver time off for a booster vaccine. Consequently, reduced waiting times or extending hours at health facilities where vaccines are administered could contribute to improved coverage levels and timeliness, particularly among vaccines for children over 1 year of age. Additionally, health services need to be more proactive in following up with the defaulters by effectively using the immunization register and the defaulter tracking system recommended by WHO (16).

Furthermore, schools need to play a more active role. If parents and caregivers fail to have their children vaccinated with MMR2 at the recommended age of 4 years, there is the opportunity to catch-up upon admission to primary school. School officials should enforce the law mandating complete vaccination status prior to enrollment. Currently, $53.2 \%$ of school entrants were not vaccinated with MMR2; after 1 year in school, $26.4 \%$ were still not vaccinated. School vaccination laws have been shown to provide an incentive for children whose vaccinations have lapsed to get up-to-date by school entry (16).

School principals can also influence the vaccination status of children. The proportion who were unaware of both the law and vaccination schedule underscores a lack of knowledge among school officials regarding their role as public health officers: to safeguard the health of those in their care. Health officials must work with education officials to sensitize school principals to vaccinations and the law, while encouraging compliance. In addition, active school health programs could identify children needing vaccinations and keep principals aware of the importance of vaccines.

Finally, gaps in coverage between the private and public sectors should also be addressed. The perception that vaccines in the private sector are more effective should be countered by informing the public that free vaccines offered in the public sector are the same as those in the private. In both, every effort is made to preserve the cold chain. Furthermore, public health authorities should work with the private health sector to emphasize the importance of timely vaccination of MMR2.

In response to these survey results, in 2016, the Ministry of Health of Saint Lucia lowered the recommended age for MMR2 to 18 months, following the guidelines of the PAHO Technical Advisory Group in 2013 (1). Saint Lucia also implemented a mop-up campaign targeting children $2-12$ years of age to close the immunity gaps identified among the older population. The country is also closely monitoring early defaulters to improve timeliness. The introduction of the electronic health information system, which includes an electronic immunization register to replace manual tracking, should facilitate all the interventions mentioned above.

In addition, "Vaccination Week in the Americas" provides an opportunity to reinforce compliance with the immunization schedule in a timely manner; this activity heavily uses media messaging and community interventions to reach rural and/or high-risk areas. Finally, immunization officers are working with the school immunization program to improve monitoring and referral of unvaccinated children to health facilities prior to school entry.

Non-response did not appear to affect data quality as the survey findings corroborated the administrative reporting of MMR2 coverage. Refusals or incomplete questionnaires were not included in the analysis. Selection error occurred due to the exclusion of children who were 11 years of age but in grade 6 of school. These children were selected when they were in grade 5 , but 
had moved on to grade 6 by the time the survey was conducted.

Limitations. A methodological limitation was the lack of a weighted analysis. This may affect the coverage estimates, but it should not change the main findings, i.e., MMR2 coverage levels well below the recommended $95 \%$ and untimely vaccination. The design using a stratified random sample normally increases efficiency-by reducing the sample size needed for more precise estimates-when the sub-population within each stratum is homogeneous, but strata populations are heterogeneous. In this study, the sampling fraction varied among schools and among grades within schools.

Furthermore, the maximum number in each cell was two, and factoring nonresponse from the private schools, some cells were empty, making model fitting impossible to converge. In addition, there is little evidence of non-homogeneity in the small population of Saint Lucia, except perhaps if classified by socioeconomic status, which was not collected. There were also some data collection errors related to transcribing vaccination cards and illegible writing. Finally, the small percentage $(4 \%)$ of children not enrolled in school was not surveyed, and thus, their immunization status was not included.

\section{CONCLUSIONS}

In conclusion, the survey contributed with estimating coverage and timeliness for MMR2, while identifying factors associated with low vaccination uptake. The findings of this study also add to the growing number of analyses of vaccination timeliness and adherence to recommended ages for administration in middle income countries. In addition, the study has produced valuable information that is being used to shape the aforementioned and other interventions, the implementation of which it is hoped, will result in the achievement of $95 \%$ vaccine coverage for MMR1 and MMR2. Lastly, the study findings support the need to implement complementary vaccination activities, such as in the school settings, to reduce the accumulation of susceptible individuals who may have transitioned into older age groups without accurate protection against measles and rubella.

Funding. Funding was provided by the Pan American Health Organization to conduct the survey of MMR2 vaccination coverage in Saint Lucia.

\section{Conflicts of interest: None declared.}

Disclaimer. Authors hold sole responsibility for the views expressed in the manuscript, which may not necessarily reflect the opinion or policy of the RPSP/PAJPH and/or PAHO.

\section{REFERENCES}

1. Pan American Health Organization. Vaccination: a shared responsibility. Proceedings of the XXI Meeting of Technical Advisory Group on Vaccine Preventable Diseases, Quito, Ecuador, 3 - 5 July 2013. Washington, DC: PAHO; 2013.

2. World Health Organization. Measles vaccines: WHO position paper. Wkly Epidemiol Rec. 2017;92(17):205-28. Available from: http:/ /apps.who.int/iris/bitstream/ 10665 / 255149/1 / WER9217.pdf?ua =1 Accessed 7 March 2018.

3. Pan American Health Organization. Immunization coverage in the Americas, by country. Washington, DC: PAHO: 2016. Available from: www.paho.org/hq/index. php?option $=$ com_content\&view $=$ article\& id=3573\&Itemid $=2573 \& l a n g=e n$ Accessed 7 March 2018.

4. Government of Saint Lucia. Laws of Saint Lucia. Public health regulations: communicable and notifiable diseases. Castries: Government of Saint Lucia; July 2001.

5. Pan American Health Organization. Health in the Americas: Regional outlook and country profiles. Washington, DC: PAHO; 2012.

6. Suarez-Castañeda E, Pezzoli L, Elas M, Baltrons R, Crespin-Elias O, Pleitez O, et al. Routine childhood vaccination programme coverage, El Salvador, 2011 - In search of timeliness. Vaccine. 2014;32(4):437-44. doi: 10.1016/j.vaccine.2013.11.072.

7. The World Bank. The Data Blog: new country classifications by income level. Available from: https://blogs.worldbank. org / opendata / new-country-classifications-2016 Accessed 7 March 2018.

8. United Nations Educational, Scientific and Cultural Organization. Education for All, 2015: national review report for Saint Lucia. Paris: UNESCO; 2014. Available from: http://unesdoc.unesco.org/images/ 0023/002300/230028E.pdf Accessed 7 March 2018.

9. Pan American Health Organization. Plan of action for maintaining measles, rubella, and congenital rubella syndrome elimination in the Region of the Americas. Proceedings of the 28th Pan American Sanitary Conference, 64th session of the WHO Regional Committee for the Americas. Washington, DC: PAHO; 2012. Available from:www.paho.org/hq/index.php?option $=$ com_docman\&task=doc_download\&gid $=41210 \&$ Itemid $=270 \&$ lang $=$ en Accessed 10 April 2018.

10. Pan American Health Organization. Plan of action on immunization, $2016-2020$. Proceedings of the $54^{\text {th }}$ Directing council, $67^{\text {th }}$ Session of the Regional Committee of WHO for the Americas. Washington, DC: PAHO; 2012. www.paho.org/hq/ index.php?option $=$ com_docman\&task $=$ doc_download \& gid $=3124$ 8\&Itemid=270\&lang=en Accessed 10 April 2018.

11. Abuya BA, Onsomu EO, Kimani JK, Moore D. Influence of maternal education on child immunization and stunting in Kenya. J Maternal Child Health. 2011;15: 1389-99.
12. Odusanya OO, Alufohai EF, Meurice FP, Ahonkhai VI. Determinants of vaccination coverage in rural Nigeria. BMC Public Health. 2008;8:381.

13. Torun SD, Bakirci N. Vaccination coverage and reasons for non-vaccination in a district of Istanbul. BMC Public Health. 2006; 6:125.

14. Tohme RA, Francois J, Wannemuehler K, Maglorie R, Danovaro-Holliday MC, Flannery B, et al. Measles and rubella vaccination coverage in Haiti, 2012: progress towards verifying and challenges to maintaining measles and rubella elimination. Trop Med Int Health. 2014;19(9): 1105-15.

15. Rainey JJ, Watkins M, Ryman TK, Sandhu P, Bo A, Banerjee K. Reasons related to non-vaccination and under-vaccination in low and middle-income countries: findings from a systematic review of the published literature, 1999 - 2009. Vaccine. 2011; 29(46):8215-21.

16. World Health Organization. Training for mid-level managers. Module 5: monitoring the immunization system. Geneva: WHO; 2008.

Manuscript received on 11 August 2017. Accepted for publication on 14 December 2017. 
RESUMEN Objetivos. Determinar con mayor precisión la cobertura y el respeto de los plazos de vacunación de la segunda dosis de la vacuna contra el sarampión, la rubéola y la parotiditis (triple viral), al tiempo que se detectan los factores asociados con la baja aceptación de esa vacuna en Santa Lucía.

\section{Cobertura de vacunación y respeto de los plazos de la segunda dosis de la vacuna triple viral en los niños nacidos en el período 2004-2009: encuesta nacional realizada en Santa Lucía en el 2015}

Palabras clave Vacuna contra el sarampión-parotiditis-rubéola; vacunación masiva; programas de

inmunización; Santa Lucia; Indias Occidentales.
Métodos. En octubre y noviembre del 2015 se llevó a cabo una encuesta centrada en niños nacidos entre el 2004 y el 2009. En 86 centros preescolares y primarios se seleccionó al azar a dos niños de cada grado, lo que arrojó un tamaño real de la muestra de 836 niños. Se analizaron los registros de salud para evaluar la cobertura y el respeto de los plazos de vacunación. Se entrevistó a los padres o tutores y los directores de las 86 escuelas sobre conocimientos, actitudes y prácticas en materia de vacunación.

Resultados. De los 767 niños incluidos, el $75 \%$ fueron vacunados con la segunda dosis de la triple viral ( $\mathrm{n}=572$ ); el $46,7 \%$ fueron vacunados a tiempo, es decir, a los 5 años de edad. La proporción más baja se dio en las cohortes nacidas en el 2004, 2005 y 2008. Se observó que las madres cuidadoras influían positivamente en el respeto de los plazos de vacunación de la segunda dosis de la triple viral. Aunque el $97 \%$ de los directores encuestados consideraba que la vacunación era importante, el 48,8\% desconocía la legislación nacional que exige la vacunación completa antes de ingresar a la escuela. Los resultados de la encuesta estaban en consonancia con las tasas bajas de cobertura administrativa de la segunda dosis de la triple viral informadas por Santa Lucía, muy por debajo del 95\% recomendado.

Conclusiones. Según los resultados de esta encuesta, el programa nacional de vacunación de Santa Lucía redujo la edad de la segunda dosis de la triple viral a los 18 meses en el 2016, aumentó las actividades de promoción en las escuelas para fomentar el cumplimiento de la ley que obliga a recibir la vacunación antes de ingresar a la escuela y está trabajando para vacunar a las cohortes de niños que no recibieron la segunda dosis de la triple viral en su debido momento.
Palavras-chave

\section{RESUMO

Cobertura e momento
oportuno de vacinação da
segunda dose da vacina
tríplice viral em crianças
nascidas em 2004-2009:
pesquisa nacional em
Santa Lúcia, 2015

Objetivos. Determinar com precisão a cobertura vacinal e o momento oportuno para ministrar a segunda dose da vacina tríplice viral (sarampo, caxumba e rubéola - SCR) e identificar os fatores associados à baixa utilização da vacina em crianças.

Métodos. Uma pesquisa direcionada a crianças nascidas de 2004 a 2009 foi realizada em Santa Lúcia em outubro e novembro de 2015. Em 86 unidades de ensino infantil e fundamental, duas crianças de cada série foram selecionadas aleatoriamente, constituindo uma amostra efetiva de 836 crianças. Dados sobre a cobertura e o momento oportuno de vacinação foram obtidos das fichas de saúde. Foram conduzidas entrevistas com os pais e/ou responsáveis e os diretores das 86 escolas sobre conhecimento, atitudes e práticas relacionadas à vacinação.

Resultados. Das 767 crianças incluídas na amostra, $75 \%$ foram vacinadas com a segunda dose de SCR $(n=572)$ e $46,7 \%$ receberam a vacina no momento oportuno (ou seja, até os 5 anos de idade). Observou-se menor proporção de vacinados nas coortes nascidas em 2004, 2005 e 2008. "Mães como cuidadoras" teve uma associação positiva com ministrar a segunda dose de SCR no momento oportuno. Apesar de $97 \%$ dos diretores entrevistados considerarem a vacinação importante, 48,8\% desconheciam a legislação nacional que exige vacinação completa para a matrícula escolar. Os resultados reforçaram a baixa cobertura vacinal da segunda dose de SCR registrada em Santa Lúcia, bem inferior ao índice recomendado de $95 \%$.

Conclusões. A partir dos resultados desta pesquisa, em 2016, o programa nacional de vacinação de Santa Lúcia reduziu para 18 meses a idade de administração da segunda dose de SCR, intensificou a recomendação para que as escolas cumpram com a legislação para matrícula escolar e está empenhado em vacinar as coortes de crianças que não receberam a segunda dose de SCR no momento oportuno.

Vacina contra sarampo-caxumba-rubéola; vacinação em massa; programas de imunização; Santa Lúcia; Índias Ocidentais. 